\title{
Adenokarsinoma Kolon: Laporan Kasus
}

\author{
Mersy S. Padang, ${ }^{1}$ Luciana Rotty ${ }^{2,3}$
}

${ }^{1}$ PPDS Bagian Ilmu Penyakit Dalam Fakultas Kedokteran Universitas Sam Ratulangi Manado

${ }^{2}$ Divisi Gastroenterologi Bagian Ilmu Penyakit Dalam Fakultas Kedokteran Universitas Sam Ratulangi Manado

${ }^{3}$ Rumah Sakit Siloam Manado

Email: mersypadang17@gmail.com

\begin{abstract}
Colorectal cancer (CRC) is a malignancy originated from the colon tissue which starts in the large intestine and rectum. In 2018, colorectal cancer was ranked fourth of the total malignancy in Indonesia with the number of cases of 30,017 (8.6\% of the total cancer cases in Indonesia). We reported a case of colon cancer (adenocarcinoma) in a female aged 34 years. Diagnosis was based on anamnesis of the presence of liquid bowel movements along with blood, intermittent abdominal pain, and change of defecation pattern. Physical examination obtained tenderness in epigastric and hypochondriac right button regions. Colonoscopy was performed and revealed a colonic tumor suspicious of adenocarcinoma, suspected chronic colitis, and internal hemorrhoid. Pathological examination of the tumor tissue resulted in colonic adenocarcinoma (moderate differentiation). The management of this patient was extensive resection with anastomosis and was planned for adjuvant therapy.
\end{abstract}

Keywords: adenocarcinoma colon cancer, colorectal cancer

\begin{abstract}
Abstrak: Kanker kolorektal (KKR) adalah keganasan yang berasal dari jaringan usus besar, yang menyerang usus besar dan rektum. Di Indonesia pada tahun 2018, kanker kolorektal menduduki posisi keempat dari keseluruhan diagnosis kanker dengan jumlah kasus 30.017 (8,6\% dari seluruh kasus kanker di Indonesia). Kami melaporkan sebuah kasus kanker kolon (adenokarsinoma) pada seorang perempuan usia 34 tahun. Diagnosis ditegakkan berdasarkan anamnesis adanya buang air besar cair diserta darah, nyeri perut hilang timbul, perubahan pola defekasi. Pada pemeriksaan fisik didapatkan nyeri tekan epigastrium dan nyeri tekan bagian hipocondria kanan. Pada pemeriksaan penunjang dilakukan kolonoskopi dan didapatkan hasil tumor kolon curiga adenocarcinoma, kolitis kronik curiga kolitis ulseratif, dan hemoroid interna. Hasil patologi anatomi dari kolonoskopi yaitu kolitis kronis dengan displasia kolon ascenden dan hasil patologi anatomi jaringan tumor berupa adenokarsinoma kolon (diferensiasi sedang). Tatalaksana yang diberikan untuk pada pasien ini berupa tindakan reseksi luas dengan anastomosis dan direncanakan untuk terapi adjuvan.
\end{abstract}

Kata kunci: adenokarsinoma kolon, kanker kolorektal

\section{PENDAHULUAN}

Kanker kolorektal (KKR) merupakan keganasan yang berasal dari jaringan usus besar, terdiri dari kolon dan/atau rektum. ${ }^{1}$ Kebanyakan kanker kolon berkembang dari polip, dan secara histopatologik sebagian besar kanker kolon merupakan adenokarsinoma (terdiri atas epitel kelenjar) dan memiliki kemampuan menyekresi mukus dengan jumlah berbeda-beda. ${ }^{2}$

Berdasarkan American Cancer Society, KKR merupakan kanker ketiga terbanyak dan kanker penyebab kematian ketiga terbanyak pada laki-laki dan perempuan di Amerika Serikat. ${ }^{1}$ Berdasarkan survei GLOBOCAN 2018, insiden KKR di seluruh dunia menempati urutan ketiga dengan jumlah kasus 1.849 .518 yaitu 10,2\% dari 
keseluruhan diagnosis kanker dan menduduki peringkat kedua sebagai penyebab kematian karena kanker (881.000 kematian ditahun 2018). Di Indonesia pada tahun 2018, kanker kolorektal menduduki posisi keempat dengan jumlah kasus 30.017 (8,6\% dari total seluruh kasus kanker di Indonesia). ${ }^{3}$

Sampai saat ini penyebab KKR tidak diketahui dengan pasti. Terdapat beberapa faktor risiko yang menyebabkan seseorang akan rentan terkena KKR yaitu polip kolorektal, riwayat KKR pada keluarga, kelainan genetik, penyakit inflamasi usus, merokok, konsumsi alkohol berlebihan, konsumsi tinggi daging merah dan daging olahan, obesitas, diabetes melitus, infeksi Helicobacter pylori dan Fusobacterium spp. ${ }^{4}$

Diagnosa KKR ditegakkan berdasarkan anamnesis, pemeriksaan fisik, dan pemeriksaan penunjang. Keluhan utama serta pemeriksaan fisik yang sering ditemukan pada semua usia berupa perdarahan per-anum disertai peningkatan frekuensi defekasi dan/atau diare selama minimal 6 minggu, teraba massa pada fossa iliaka dekstra, adanya tanda-tanda obstruksi mekanik, dan anemia defisiensi besi. Pada pasien di atas 60 tahun adanya perdarahan per-anum tanpa diserta gejala anal atau adanya peningkatan frekuensi defekasi atau diare selama minimal 6 minggu dapat dicurigai ke arah KKR. Pemeriksaan colok dubur sebaiknya dilakukan pada setiap pasien dengan gejala anorektal dengan tujuan menilai keutuhan sfingter ani dan menetapkan ukuran serta derajat fiksasi tumor pada rektum 1/3 tengah dan distal. ${ }^{5}$

Pemeriksaan penunjang untuk KKR antara lain pemeriksaan darah, darah samar feses, serta pemeriksaan radiologi yang disarankan seperti enema dengan Double Contrast, CT Scan abdomen dan pemeriksaan kolonoskopi untuk membantu menegakkan diagnosis. $^{5}$

Pilihan terapi pada KKR antara lain terapi operasi dan kemoterapi adjuvan. Terapi operasi seperti reseksi total dari tumor apabila memungkinkan lalu dilakukan biopsi untuk penilaian metastasis. Kemoterapi adjuvan memiliki peran pen- ting untuk pasien dengan risiko tinggi. Studi menunjukkan bahwa pada kasus KKR operasi yang diikuti oleh kemoterapi 5-FU berbasis adjuvan memberikan mafaat dalam hal kelangsungan hidup bebas penyakit. ${ }^{6}$ Mengingat tingginya kejadian kasus KKR serta mortalitasnya di seluruh dunia maka berikut ini dipaparkan sebuah kasus seorang pasien dengan kanker kolorektal.

\section{LAPORAN KASUS}

Seorang pasien perempuan WO, usia 34 tahun, suku Bolaang Mongondow, alamat Kotamobagu, pekerjaan ibu rumah tangga, agama Islam, masuk Rumah Sakit Siloam Manado pada tanggal 29 Januari 2020 dengan keluhan utama buang air besar cair berdarah. Buang air besar cair bercampur darah dialami pasien sejak 3 bulan terakhir. Buang air besar disertai dengan darah segar dan terkadang terasa nyeri saat hendak buang air besar. Sebelum mulai buang air besar cair berdarah pasien sering sulit buang air besar, sekalipun rasa ingin buang air besar ada tetapi tinja tidak bisa keluar. Nyeri perut hilang timbul yang berulang sejak 6 bulan terakhir. Nyeri perut seperti melilit terutama saat malam hari. Pasien hanya minum obat lambung saat merasakan nyeri perut tersebut. Penurunan berat badan tidak ada. Mual dirasakan 2 minggu terakhir, tidak disertai muntah. Pasien tidak mengeluhkan demam, batuk, dan sesak nafas. Saat ini pasien sedang hamil pertama dengan usia kehamilan 8 minggu. Pasien merupakan pasien konsul dari Bagian Bedah untuk evaluasi lebih lanjut karena kecurigaan keganasan pada saluran cerna.

Riwayat penyakit hipertensi, diabetes, kolesterol, hati, asam urat, ginjal dan paru disangkal oleh pasien. Mengenai riwayat kebiasaan, pasien tidak merokok dan tidak mengonsumsi alcohol. Riwayat kebiasaan mengonsumsi makanan dengan jumlah serat yang rendah, pasien lebih suka makan daging dan ikan dalam jumlah yang banyak dibandingkan sayur dan buah-buahan. Tidak ada anggota keluarga yang mengalami penyakit serupa. Riwayat alergi obat 
dan makanan tidak ada.

Pada pemeriksaan fisik didapatkan keadaan umum tampak sakit sedang dengan kesadaran compos mentis, berat badan 55 $\mathrm{kg}$, tinggi $160 \mathrm{~cm}$, indeks massa tubuh (IMT) $21,48 \mathrm{~kg} / \mathrm{m}^{2}$ dengan kesan berat badan normal, tekanan darah 100/70 $\mathrm{mmHg}$, nadi 92 kali per menit regular, isi cukup, pernapasan 20 kali per menit, suhu badan $36,9^{\circ} \mathrm{C}$, dan saturasi oksigen $98 \%$. Pada pemeriksaan kepala ditemukan konjungtiva anemis, sklera tidak ikterik, bibir tidak sianosis, dan faring tidak hiperemis. Pemeriksaan trakea letak tengah, tekanan vena jugularis normal, pembesaran kelenjar tiroid tidak ada, pembesaran kelenjar getah bening tidak ada. Pemeriksaan dada tampak simetris kiri dan kanan, fremitus raba kiri dan kanan sama, perkusi sonor pada paru kiri dan kanan, batas paru hati pada ruang iga IV, suara napas vesikuler, dan tidak terdapat ronki maupun mengi. Pada pemeriksaan jantung iktus kordis tidak tampak, palpasi iktus kordis tidak teraba, tidak ada fibrasi, batas jantung kanan di sela iga IV garis sternalis kanan, batas jantung kiri di sela iga $\mathrm{V}$, terletak pada garis aksilaris anterior kiri, bunyi jantung satu dan dua normal, teratur, bising tidak ada. Pada pemeriksaan perut tampak datar, bising usus dalam batas normal, pada palpasi perut lemas, terdapat nyeri tekan epigastrium dan nyeri tekan regio hipokondria kanan, hepar dan lien tidak teraba, nyeri ketok sudut kostofrenikus tidak ada pada sisi kiri dan kanan. Pada perkusi ditemukan timpani di seluruh abdomen. Pada pemeriksaan anggota gerak tungkai tidak ada edema, dan akral teraba hangat,

Pada pemeriksaan laboratorium tanggal 02 Februari 2020 didapatkan leukosit $18.500 / \mathrm{mm}^{3}$; eritrosit $4,02 \times 10^{6} \mathrm{~mm}^{3}$; hemoglobin $(\mathrm{Hb}) 11 \mathrm{gr} / \mathrm{dL}$; hematokrit 32,8\%; trombosit 501.000/uL; MCH 27,4 pg; MCV 81,6 fL; MCHC 33,5 g/dL; SGOT $11 \mathrm{U} / \mathrm{L}$; SGPT $10 \mathrm{U} / \mathrm{L}$; natrium $136 \mathrm{meq} / \mathrm{l}$; kalium 3,2 meq/l; klorida $101 \mathrm{mEq} / \mathrm{L}$; dan gula darah sewaktu (GDS) $93 \mathrm{mg} / \mathrm{dL}$. Hasil EKG memperlihatkan gambaran sinus rhytme, $90 \mathrm{x} / \mathrm{mnt}$. Hasil USG tanggal 27 Desember 2019 tampak lesi heterogen, sirkuler, bentuk menyerupai pseudo kidney, ukuran $\pm 6,82 \times 3,9 \times 6,12 \mathrm{~cm}$ regio hipokondria kanan. Pada kantong empedu, dinding tidak menebal, mukosa reguler, tampak echo batu dengan ukuran $\pm 0,51 \mathrm{~cm}$. Tampak cairan pada cavum Douglasi. Dari hasil pemeriksaan USG disimpulkan curiga massa intralumen, batu empedu, dan tandatanda pelvic inflammatory disease (PID).

Berdasarkan anamnesis, pemeriksaan fisik, laboratorium, dan pemeriksaan penun jang ditegakkan diagnosis suspek tumor kolon, infeksi bakterial, hipokalemia, dan G1P0A0, 34 tahun, hamil 8-9 minggu. Pasien direncanakan untuk tindakan kolonoskopi dan diberikan terapi IVFD Nacl 0,9\% + KCl 25 meq/24 jam, meropenem $1 \times 2$ gr iv, dan asam traneksamat $3 \times 500 \mathrm{mg}$ iv.

Pada hari perawatan ketujuh, pasien dilakukan kolonoskopi dengan hasil pada anus ditemukan hemoroid interna, pada kolon sigmoid hingga kolon transversum ditemukan adanya mukosa yang erosi, kemudian dilakukan biopsi masing-masing 1 keping mulai rektum sampai kolon transversum. Pada kolon asenden sampai sekum ditemukan massa berbenjol rapuh, mudah berdarah $75 \mathrm{~cm}$ dari anus, menutupi lumen, kemudian dilalukan biopsi 4 keping. Dari pemeriksaan kolonskopi disimpulkan tumor kolon asenden curiga adenokarsinoma, kolitis kronis curiga kolitis ulseratif, dan hemoroid interna. Berdasarkan hasil pemeriksaan ini pasien didiagnosis dengan tumor kolon asenden curiga adenokarsinoma, kolitis kronis curiga kolitis ulseratif, dan hemoroid interna. Jaringan yang dibiopsi diperiksa di Pusat Diagnostik Patologi Anatomi Manado dan disarankan untuk melakukan pemeriksaan fecal calprotectin. Pasien dipulangkan sambil menunggu hasil pemeriksaan patologi anatomi dan fecal calprotectin.

Dua minggu kemudian, pasien kembali masuk rumah sakit karena kehamilannya tidak dapat dipertahankan dan dilakukan kuretase oleh dokter spesialis kandungan. Hasil kuratese dikirim untuk pemeriksaan patologi anatomi. Hasil patologi anatomi dari jaringan kuretase yaitu ditemukan 
jaringan berupa bekuan darah, jaringan desidua, vili korialis, dan sel-sel trofoblas. Tidak ditemukan keganasan pada sediaan dan disimpulkan sisa kehamilan.

Pada pemeriksaan patologi anatomi dari hasil kolonoskopi berupa 5 botol jaringan yang dikirimkan ditemukan hasil sebagai berikut: sediaan kolon asenden menunjukkan hasil lapisan mukosa dengan beberapa kelenjar displasia, stroma fibrous dan sebukan sel-sel limfosit; sediaan kolon trasversum menunjukkan hasil adanya infiltrasi sel limfosit di antara kelenjar mukosa; sediaan kolon desenden dan sigmoid serta rektum menunjukkan hasil infiltrasi limfosit; sehingga disimpulkan sebagai kolitis kronis dengan displasia kolon asenden. Hasil pemeriksaan fecal calprotectin menunjukkan kadar fecal calprotectin sebesar 729,4 $\mu \mathrm{g} / \mathrm{g}$. Berdasarkan hasil tersebut pasien diagnosis sebagai kolitis ulseratif dengan displasia kolon asenden, suspek adenokarsinoma kolon, dan hemoroid interna, kemudian pasien kontrol ke poli bedah dan direncakan untuk dilakukan operasi dengan diagnosis tumor kolon.

Pada tanggal 16 Maret 2020 dilakukan tindakan hemikolektomi dekstra. Dilakukan insisi pada dinding abdomen kemudian dilakukan eksplorasi laparatomi dengan hasil tidak terdapat nodul di hepar, tampak tumor kolon asenden, usus tidak dilatasi, dan terdapat pembesaran kelenjar getah bening mesenterium. Tumor diangkat dan dilakukan ligasi ileocolica dan anastomosis ileocolica end to end. Sampel tumor dikirim untuk pemeriksaan patologi anatomi. Hasil pemeriksaan patologi anatomi sebagai berikut: secara makroskopik diterima jaringan usus ukuran $14 \times 9 \times 7 \mathrm{~cm}$ sudah dibelah, putih kuning, diproses sebagian. Secara mikroskopik dari sediaan jaringan ujung-ujung eksisi dilapisi oleh mukosa intestinalis dengan stroma tanpa kelainan tertentu. Sediaan jaringan tumor terdiri dari proliferasi kelenjar dilapisi oleh beberapa lapis sel epitel yang pleomorfik, inti atipik, kromatin kasar, tersusun ireguler dan infiltrasi di antara stroma sampai lapisan muskular, dan disimpulkan sebagai adeno- karsinoma kolon (diferensiasi sedang). Pasien direncanakan untuk perawatan selanjutnya.

\section{BAHASAN}

Kanker kolorektal (KKR) adalah suatu keganasan yang berasal dari jaringan usus besar, yang menyerang usus besar dan rektum. ${ }^{1}$ Menurut penelitian KKR merupakan kanker terbanyak ketiga pada laki-laki dan perempuan. Probabilitas perkembangan KKR di Amerika Serikat ialah 5\% pada laki-laki dan $4,6 \%$ pada perempuan dengan usia rerata saat diagnosis ialah sekitar 70 tahun. $^{7}$ Di Indonesia pada tahun 2018, KKR menduduki posisi keempat dengan jumlah kasus $30.017 \quad(8,6 \%$ dari total seluruh kasus kanker di Indonesia). Insiden KKR pada laki-laki sebesar $11,9 \%$ dan pada perempuan sebesar $5,8 \%$ dari total kejadian seluruh jenis kanker di Indonesia. ${ }^{3}$ Sebuah meta-analisis dari 17 studi yang terdiri dari 924.932 pasien menunjukkan laki-laki berisiko secara bermakna lebih besar daripada perempuan untuk perkemangan KKR di semua kelompok usia. ${ }^{8}$ Pada kasus ini, pasien seorang perempuan berusia 34 tahun.

Penyebab KKR sampai saat ini tidak diketahui dengan pasti. Terdapat beberapa faktor risiko yang menyebabkan seseorang akan rentan terkena KKR yaitu polip kolorektal, riwayat KKR pada keluarga, dan kelainan genetik seperti faktor keturunan yaitu familial adenomatosa polyposis (FAP) dan keturunan non-poliposis KKR (Lynch sindrom) mencapai 5\% dari kasus KKR. Pasien dengan kolitis ulseratif atau penyakit Crohn meningkatkan risiko KKR $5 \%$ dengan durasi selama >20 tahun; merokok memiliki risiko $18 \%$ lebih tinggi pada KKR daripada yang tidak pernah merokok; konsumsi alkohol yang berlebihan meningkatkan sekitar $11 \%$ pada KKR; konsumsi tinggi daging olahan meningkatkan resiko KKR secara linear dengan konsumsi daging olahan hingga 140 gram setiap hari; obesitas (indeks massa tubuh >30) meningkatkan risiko KKR dibandingkan individu dengan IMT normal; pasien dengan diabetes dikaitkan dengan 
risiko 30\% lebih tinggi pada $\mathrm{KKR}$; serta infeksi Helicobacter pylori dan Fusobacterium spp. ${ }^{9}$ Kolitis ulserativa menyebabkan terjadinya kanker kolon dan paling banyak terdapat di bagian proksimal dari kolon, dimulai dengan mikroabses pada kripta mukosa kolon dan beberapa abses bersatu membentuk ulkus. Pada stadium lanjut timbul pseudopolip yaitu penonjolan mukosa kolon di antara ulkus. Perjalanan penyakit yang sudah lama, berulang-ulang dan lesi luas disertai adanya pseudopolip merupakan risiko tinggi terjadinya kanker. ${ }^{10}$ Pada kasus ini ditemukan pasien memiliki faktor risiko berupa konsumsi daging yang sering disertai rendahnya jumlah serat yang dikonsumsi. Selain itu pada pasien ini ditemukan adanya gambaran kolitis pada hasil kolonoskopi dan kadar fecal calprotectin tinggi yang menggambarkan adanya suatu kolitis ulseratif yang juga merupakan salah satu faktor risiko untuk berkembangnya suatu KKR.

Gejala klinis KKR tergantung pada lokalisasi tumor. Gejala paling umum KKR yang terlihat ialah sakit perut, perubahan kebiasaan buang air besar, perdarahan rektum, dan anemia defisiensi besi, meskipun gejala ini biasanya dapat juga ditemukan pada penyakit saluran cerna lainnya. ${ }^{9}$ Tumor kolorektal sisi kiri biasanya hadir dengan kebiasaan buang air besar yang berubah seperti diare, peningkatan frekuensi, dan obstruksi usus sekunder sampai penyempitan lumen progresif, perdarahan rektum atau lendir, atau tenesmus. Lesi sisi kanan dapat hadir lebih diam-diam dengan penurunan berat badan, sakit perut atau massa pada perut bagian kanan, dan terjadi anemia defisiensi zat besi. ${ }^{9,11}$ Pada tumor terlokalisir di kolon transversum, gejala utamanya ialah obstruksi dengan rasa sakit postprandial di perut, meteorismus dan diare, serta pada kasus berat dapat terjadi ileus dan perforasi. Karsinoma bagian rektosigmoid memperlihatkan gejala tenesmus atau nyeri saat buang air besar, diameter tinja lebih tipis, dan hematoschezia. ${ }^{12}$ Pada kasus ini ditemukan adanya keluhan buang air besar disertai darah segar, nyeri perut, adanya perubahan pola buang air besar, tenesmus, serta anemia.

Pada kasus KKR dilakukan pemeriksaan laboratorium darah untuk mengetahui terdapatnya anemia defisiensi besi. Panduan hemoglobin untuk rujukan KKR menggunakan cut-off di bawah $12 \mathrm{gr} / \mathrm{dL}$ untuk perempuan dan $13 \mathrm{gr} / \mathrm{dL}$ untuk lakilaki. Beberapa studi mengemukakan bahwa kadar zat besi menurun seiring dengan meningkatnya stadium penyakit KKR, sehingga pasien menjadi lebih anemia, dan lebih banyak kekurangan zat besi bersamaan dengan perkembangan penyakit. Tren penurunan kadar $\mathrm{Hb}$ berkorelasi dengan tren penurunan serum besi dan kadar transferin jenuh. ${ }^{13}$ Pada kasus ini ditemukan adanya anemia berupa kadar $\mathrm{Hb} 11 \mathrm{gr} / \mathrm{dL}$.

Pada pemeriksaan penunjang sejumlah intervensi diagnostik yang berbeda telah digunakan untuk mendeteksi KKR. Pemeriksaan penunjang seperti kolonoskopi, barium enema/sigmoidoskopi fleksibel dan computerized tomography colonography (CT colonography), tetapi strategi diagnostik yang optimal untuk KKR belum pernah didefinisikan. ${ }^{14}$ Selama bertahuntahun kolonoskopi telah dianggap sebagai standar referensi untuk mendiagnosis kelainan pada kolon. Kolonoskopi dikenal memiliki sensitivitas $(95 \%)$ dan spesifisitas (99\%) paling tinggi untuk deteksi kanker dan adenoma pre-malignan serta penyakit kolon lainnya. ${ }^{15}$ Selain itu, kolonoskopi juga memiliki fasilitas untuk pengambilan sampel biopsi dari lesi yang dicurigai sehingga meningkatkan akurasi diagnostik dan memungkinkan pengangkatan lengkap lesi yang mencurigakan. Dengan endoskopi sulit untuk dibedakan jenis-jenis polip secara histologik; oleh karena itu biopsi dan polipektomi penting untuk menegakkan diagnosis secara histologik. CT colonography merupakan pemeriksaan radiologi yang lebih baru dimana gambar penampang dari perut dan panggul diperoleh mengikuti persiapan pencahar dan insuflasi dari usus besar dengan udara atau karbondioksida. CT colonography mungkin mendekati sensitivitas kolonoskopi untuk mendeteksi polip yang lebih besar $(>1 \mathrm{~cm})$ dan komplikasi yang minimal dikarenakan kurang 
invasif dibandingkan kolonoskopi dan tidak memerlukan sedasi pasien. Pada $C T$ colonography dihasilkan gambar dari semua organ perut dan panggul; hal ini dapat memberikan kesempatan temuan klinis penting kelainan di tempat lainnya. ${ }^{16}$ Pada kasus ini dilakukan tindakan kolonoskopi dan ditemukan massa berbenjol rapuh, mudah berdarah sekitar $75 \mathrm{~cm}$ dari anus, menutupi lumen, dan berdasarkan hasil patologi anatomi ditemukan kolitis kronis dengan displasia kolon ascenden.

Tingkat kesembuhan dan kelangsungan hidup tergantung pada stadium KKR. Klasifikasi tahapan kanker digunakan untuk menentukan luas atau ekstensi kanker dan nilai prognostik pasien. Sistem yang paling banyak digunakan ialah sistem TNM American Joint Committee on Cancer (AJCC) 2010. ${ }^{5}$ Gambaran histologik yang dominan menentukan klasifikasi adenoma. Jenis adenoma yang paling sering ialah adenoma tubular $(85 \%)$, adenoma tubulevilosum (10\%), dan adenoma serrata (1\%). Temuan sel atipik pada adenoma dikelompokkan menjadi ringan, sedang, dan berat. Gambaran atipik berat menunjukkan adanya fokus karsinomatosus namun belum menyentuh membran basalis. Bilamana sel ganas menembus membran basalis tetapi tidak melewati muskularis mukosa disebut karsinoma intramukosa. ${ }^{15}$ Klasifikasi histopatologik kanker kolorektal oleh World Health Organization dan direkomendasikan oleh College of American Pathologists (CAP) menunjukkan mayoritas kanker kolorektal ialah adenokarsinoma no special type ${ }^{17}$ Grading karsinoma kolorektal, secara keseluruhan dinilai berdasarkan arsitektur dan sitologi (contoh pleomerfism, hiperkromatisme, dan produksi musin) tetapi derajat bentuk kelenjar secara luas yang paling penting dalam grading. ${ }^{18}$ Sebagian besar sistem stratifikasi tumor dibagi atas 4, yaitu: grade 1, well differentiated; grade 2, moderately differentiated; grade 3 , poorly differentiated; dan grade 4 , undifferentiated. ${ }^{18}$ Pada pasien ini ditemukan hasil biopsi dari tindakan hemikolektomi dekstra didapatkan secara makroskopik jaringan usus ukuran $14 \times 9 \times 7 \mathrm{~cm}$ dan secara mikroskopik terdiri dari sediaan jaringan ujung-ujung eksisi dilapisi oleh mukosa intestinalis dengan stroma tanpa kelainan tertentu. Sediaan jaringan tumor terdiri dari proliferasi kelenjar dilapisi oleh beberapa lapis sel epitel yang pleomorfik, inti atipik, kromatin kasar, tersusun ireguler dan infiltratif diantara stroma sampai lapisan muskular, dan disimpulkan sebagai adenokarsinoma kolon (diferensiasi sedang) Berdasarkan hasil tersebut, kasus ini diklasifikasikan sebagai T3N1M0 yang artinya pasien dalam stadium IIIB.

Penatalaksanaan KKR bersifat multidisiplin. Pilihan dan rekomendasi terapi tergantung pada beberapa faktor Terapi bedah merupakan modalitas utama untuk kanker stadium dini dengan tujuan kuratif. Kemoterapi ialah pilihan pertama pada kanker stadium lanjut dengan tujuan paliatif. Penatalaksanaan kanker kolorektal dibedakan menjadi penatalaksanaan kanker kolon dan kanker rektum. ${ }^{5}$ Pada kasus ini dilakukan reseksi tumor dan anastomosis ileocolica end to end dan pasien direncanakan untuk pemberian kemoterapi adjuvan.

Tingkat kekambuhan, bertahan hidup, dan manajemen berbeda tergantung tahap KKR. Diagnosis dan penentuan stadium sangat penting untuk memastikan strategi pengobatan yang benar. Dalam 10 tahun terakhir angka kematian KKR telah menurun lebih dari $20 \%$ karena meningkatnya perkembangan teknik diagnostik dan optimalisasi bedah, kemoterapi adjuvan, dan juga terapi paliatif. Pemeriksaan kolonoskopi ditambah dengan biopsi untuk pemeriksaan histopatologik dianggap sebagai baku emas untuk mendiagnosis lesi kolorektal. Prosedur ini dapat menentukan lokalisasi tumor dan kemungkinan eksisi polip endoskopi sehingga secara simultan dapat menunjukkan kesempatan diagnosis dan terapeutik. Pada sebagian besar pasien dengan penyakit terlokalisir tumornya, reseksi akan menjadi pengobatan pilihan dengan pertimbangan diberikan kemoterapi adjuvan setelah reseksi. Pada pasien dengan penyakit metastasis akan dipertimbangkan untuk kemoterapi paliatif. ${ }^{19}$ Pada kasus ini telah dilakukan reseksi dan 
rencana pemberian kemoterapi adjuvan.

Tingkat kelangsungan hidup 5 tahun bagi kasus KKR ialah $65 \%$. Namun, tingkat kelangsungan hidup untuk kasus KKR dapat bervariasi berdasarkan berbagai faktor, terutama stadium. ${ }^{20}$ Tingkat kelangsungan hidup 5 tahun tergantung pada tahap di KKR sesuai dengan Union for International Cancer Control (UICC). Tingkat kelangsungan hidup 5 tahun penderita kanker stadium 1 kolorektal ialah 93,2\%. Pada kanker yang menyebar ke jaringan sekitarnya atau organ dan/atau kelenjar getah bening regional tingkat kelangsungan hidup 5 tahun ialah $64,1 \%$. Jika kanker telah menyebar ke bagian tubuh yang jauh dari primernya maka tingkat kelangsungan hidup 5 tahun adalah $8,1 \% .^{6}$ Pada kasus ini berdasarkan UICC maka tingkat kelangsungan hidup 5 tahun sebesar $64,1 \%$. Prognosis pada kasus ini ialah dubia ad malam karena sudah menjalani kolonoskopi, dan reseksi tumor dengan anastomosis tetapi belum setuju untuk diberikan kemoterapi adjuvan.

\section{SIMPULAN}

Telah dilaporkan sebuah kasus kanker kolon (adenokarsinoma) pada seorang perempuan usia 34 tahun. Diagnosis ditegakkan berdasarkan anamnesis adanya buang air besar cair disertai darah, nyeri perut hilang timbul, dan perubahan pola defekasi. Pada pemeriksaan fisik didapatkan nyeri tekan epigastrium dan regio hipokondria kanan. Pada pemeriksaan penunjang kolonoskopi didapatkan hasil tumor kolon curiga adenokarsinoma, kolitis kronik curiga kolitis ulseratif, serta hemoroid interna. Hasil patologi anatomi dari kolonoskopi yaitu kolitis kronis dengan displasia kolon asenden dan hasil patologi anatomi jaringan tumor berupa adenokarsinoma kolon (diferensiasi sedang). Tatalaksana yang diberikan berupa tindakan reseksi luas dengan anastomosis dan direncanakan untuk kemoterapi adjuvan. Prognosis pasien ini ialah dubia ad malam.

\section{Konflik Kepentingan}

Penulis menyatakan tidak terdapat konflik kepentingan dalam studi ini.

\section{DAFTAR PUSTAKA}

1. Alteri R, Brooks D, Gansler T, Henning A, Jacobs E, Kirkland D, et al. Colorectal Cancer Facts \& Figures 2014-2016. Atlanta: American Cancer Society, 1-24.

2. Sjamsuhidajat. Pengelolaan Karsinoma Kolorektal (Suatu Panduan Klinis Nasional). Jakarta: Kelompok Kerja Adenokarsinoma Kolorektal Indonesia, 2004.

3. BrayF, Ferlay J, Soerjomataram I, Siegel RL, Torre LA, Jemal A. Globalcancer statistics 2018: GLOBOCAN estimates of incidence and mortality worldwide for 36 cancers in 185 countries. CA Cancer J Clin. 2018;68(6):394-424.

4. Johnson CM, Wei C, Ensor JE, Smolenski DJ, Amos CI, Levin B, et al. Metaanalyses of colorectal cancer risk factors. Cancer Causes Control. 2014; 24:1207-22.

5. Kementerian Kesehatan Republik Indonesia Komite Penanggulangan Kanker Nasional (KPKN). Panduan Penatalaksanaan Kanker kolorektal. KPKN, 2015; p. 4.

6. Stinzing S. Management of colorectal cancer. F1000Prime Reports. 2014;6:108.

7. Arnold M, Sierra MS, Laversanne M, Soerjomataram I, Jemal A, Bray F, et al. Global patterns and trends in colorectal cancer incidence and mortality. Gut. 2016;0:1-9

8. Nguyen SP, Bent S, Chen YH, Terdiman JP. Gender as a risk factor for advanced neoplasia and colorectal cancer: a systematic review and meta-analysis. Clin Gastroenterol Hepatol. 2009;7: 676-81.e1, 3.

9. Thrumurthy SG, Thrumurthy SSD, Gilbert CE, Ross P, Haji A. Colorectal adenocarsinoma: risks, prevention and diagnosis. BMJ. 2016;353:i3590.

10. Haggar FA, Boushey RP. Colorectal cancer epidemiology: Incidence, mortality, survival, and risk factors. Clin Colon Rectal Surg. 2009;22(4):191-7.

11. Kanellos D, Kitsios G, Kanellos I, Demetriades H, Pramateftakus MG, Angelopoulos S, et al. Anaemia as a symptom of right colon cancer. Tech Coloproctol 2004;8(Suppl1):s62-4.

12. Marija P. Clinical presentation and the clearly detection of colorectal cancer. Global 
Journal of Medicine and Public Health (GJMEDPH). 2015;4(4):1-6

13. The National Institute for Health and Clinical Excellence (NICE). Colorectal cancer: the diagnosis and management of colorectal cancer. NICE, 2011; p.1-185.

14. Rosa MD, Pace U, Rega D. Genetics, diagnosis and management of colorectal cancer (review). Oncology Reports. 2015;34:1087-96.

15. Abdullah M. Tumor kolorektal. In: Buku Ajar Ilmu penyakit Dalam Jilid III (6th ed). Jakarta: Pusat Penerbitan Ilmu Penyakit Dalam, 2014; p. 3023-31.

16. Sirohi B, Shrikhande SV, Perakath B, Raghunandharao D, Julka PK, Lele $\mathrm{V}$, et al. Indian Council of Medical Research. Consensus document for management of colorectal cancer. Indian J Med Paediatr Oncol. 2014;
35(3):192-6

17. Fleming M, Ravula S, Tatishchev SF, Wang H. Colorectal carcinoma: pathologic aspects. J Gastrointest Oncol. 2012; 3(3): 153-73

18. Barresi V, Bonetti LR, Leni A, Caruso RA, Tuccari G. Histological grading in colorectal cancer: New insights and perspectives. Histol Histopathol. 2015; 30(9):1059-67.

19. Moghimi-Dehkordi B. An overview of colorectal cancer survival rates and prognosis in Asia. World J Gastrointest Oncol. 2012;4(4):71.

20. Majek O, Gondos A, Jansen L, Emrich K, Holleczek B, Katalinic A. Sex differences in colorectal cancer survival: population-based analysis of 164,996 colorectal cancer patients in Germany. PLoS ONE. 2013;8(7):1-7. 